EGU21-10566

EGU General Assembly 2021

(c) Author(s) 2021. This work is distributed under

the Creative Commons Attribution 4.0 License.

\title{
Geodiversity of proglacial areas and implications on abiotic ecosystem services
}

\author{
Irene Maria Bollati ${ }^{1}$, Cristina Viani ${ }^{2}$, Anna Masseroli ${ }^{1}$, Giovanni Mortara ${ }^{3}$, Bruno Testa ${ }^{4}$, Gianluca \\ Tronti ${ }^{1}$, Emmanuel Reynard ${ }^{5}$, and Manuela Pelfini ${ }^{1}$ \\ ${ }^{1}$ Università degli Studi di Milano, Earth Science Department A. Desio, Milan, Italy (irene.bollati@unimi.it; \\ anna.masseroli@unimi.it; gianluca.tronti@unimi.it; manuela.pelfini@unimi.it) \\ ${ }^{2}$ Università degli Studi di Torino, Earth Science Department, Turin, Italy (cristina.viani@unito.it) \\ ${ }^{3}$ CNR-IRPI, Turin, Italy (giovanni.mortara@irpi.cnr.it) \\ ${ }^{4}$ CNR-IGAG, Milan, Italy (bruno.testa@igag.cnr.it) \\ ${ }^{5}$ Institute of Geography and Sustainability and Interdisciplinary Centre for Mountain Research, Bramois, Switzerland \\ (emmanuel.reynard@unil.ch)
}

Proglacial areas, defined as the areas left free from glaciers since the Little Ice Age, are open-air laboratories to study the effects of climate change on high mountain environments. Their different abiotic features (i.e. geodiversity) depend mainly on the bedrock characteristics, the type of glaciers acting in the areas and the morphometry of their hydrographic basins, which influence the geomorphic dynamics (i.e., geomorphodiversity). From this, it could derive a different response of glacier forefields to deglaciation and particular evolutionary trends. Hydrological elements and dynamics are particularly variable (i.e. hydrogeodiversity), especially in terms of proglacial lakes diversification, having effects down-valley, even far from the strict proglacial area, and also in term of potential natural hazards. Moreover, geodiversity of proglacial areas may have implications on other types of "diversity". After the glacier retreat, glacier forefields are, in fact, characterized by soils development and vegetation settlement. In particular, soils characterized by different ages and by different degree of development coexist over short distances (i.e. pedodiversity), functioning also as a support for living organisms. Biotic components gradually colonize such areas, from the pioneer to the late-successional species, bringing varied species along the proglacial plains (i.e. biodiversity). All these aspects can be discussed in the perspective of the abiotic ecosystem services (i.e. regulating, supporting, provisioning, and cultural) provided by glacier forefields. Regulating services are related to both atmospheric and terrestrial processes, including natural hazard regulation. Supporting services deal mainly with habitat provision and soils development. Provisioning services include both material (freshwater, building materials) and immaterial (i.e. tourism) resources. Finally, cultural services, that are the most numerous, take into account, among the others, the spiritual and historical meaning, the geohistorical importance for the Earth Sciences development, the educational and geotourism-related opportunities, and the landscape benefit effects. Considering all these aspects, and the intense dynamics proglacial areas are affected by, which will be illustrated through examples mainly from the European Alps, it emerges the importance of a careful monitoring and management of such areas, hopefully through an even more holistic approach. 
